\title{
The Challenges of Indonesia's Foreign Policy towards Palestine
}

\author{
Nadia Sarah Azani and Muhammad Luthfi Zuhdi \\ Middle Eastern and Islamic Studies, Universitas Indonesia
}

\begin{abstract}
Indonesia has a firm position in supporting Palestine which reflected by its continuous supports in number of international forums such as UN, OIC, and Non-Aligned Movement. It is also a mandate as stated in the 1945 constitution, that Indonesia will stand against and opposes all forms of colonialism. In the context of Israel and Palestine conflict, Indonesia will continue to support the effort of Palestinian people to struggle for independency. This research discusses the role of Indonesia and its commitment to support Palestine which reflected in the foreign policies. Indonesia's foreign policy towards Palestine opens the door of opportunities and challenges in many aspects including the domestic and international level of both Indonesia and Palestine. The challenges may change the role of Indonesia that would impact on gaining a greater influence in pursuing the peace in Middle East. While it may also changes the political situation between Fatah and Hamas in Palestine. To analyze numbers of upcoming opportunities and challenges, the theory of foreign policy approach by James $N$. Rosenau will be employed. The method used in this study is qualitative with descriptive-analysis approach, while the data will be obtained by book reviews, journals, articles, newspapers, internet, and also from interviews.
\end{abstract}

Keywords: Indonesia, Palestine, foreign policy, UN, OIC, Non-Aligned Movement, Hamas, Fatah.

\section{Introduction}

Indonesia has a firm position in supporting the struggle of Palestinian since the independent of Indonesia in 1945. As stated in the preamble of Indonesia's constitution that Indonesia ought to "participate in the establishment of world order based on freedom, lasting peace and social justice." ${ }^{[1]}$ In the context of foreign policy, Indonesia tends to perform as bebas (independent) which meant its position was not including in one of the two blocks and had its own way to solve international problems ${ }^{[2]}$, and aktif (active) or an attempt to work harder in order to maintain peace and ease tensions between the two blocks. ${ }^{[3]}$

The Palestinian issues had always been a strong topic in Indonesian society as it has the largest Muslim population in the world today. Although Indonesia's position towards Palestinian not only reflected by the religious obligation but also according to the mandate of constitution to fight against any form of colonisation. The strong position not only embodied by the attitude and policies of the Indonesian government alone but the Indonesian people contribute a greater role in supporting the Palestinian people. There are many humanitarian agencies or NGOs such as Komite Nasional untuk Rakyat Palestina (KNRP), Aksi Cepat Tanggap (ACT), Mer$\mathrm{C}$, etc. which actively contribute in sending all kinds of aid to the Palestinian people. It can be viewed that Indonesia's activities related to Palestine issues are represented not only through inter-state relations, but also through the framework of multi-track diplomacy.

The research question of this study is what are the challenges of Indonesia's foreign policy toward Palestine that would be faced by Indonesia? This study aims to map Indonesia's position that should be put forward by Indonesia concerning the Israeli-Palestinian conflict. This study is important because the Palestinian issue has become part of Indonesian society's attention and is expected to be a contribution that should be considered by the government.

\section{Research Method and Theoretical Approach}

This research employed a qualitative approach and the analysis is presented by descriptive analysis. Data collection techniques are reviewing the sources of both primary and secondary data that obtained from the books and website articles published by the Ministry of Foreign Affairs of the Republic of Indonesia. The secondary sources are from books, journals, thesis, news and articles on the internet, and also interviews.

This research employed three variables of foreign policy approaches from James N. Rosenau, the first is ideosinkratik variable where the individual factors are defined as unique and special nature of a leader or 
decision maker determines and implements foreign policy. ${ }^{[4]}$ National variables are associated with internal conditions of the country and affect international issues such as the dominant of value orientation in society, the level of national unity, the political level, industrialization and the economy are a bit much contributed to the content of the aspirations and foreign policy. ${ }^{[5]}$ Sistemile variable deals with aspects of the external environment of the state or the actions that occurred abroad and influence the choices made by decision-makers. ${ }^{[6]}$

Indonesia's foreign policy towards the Palestinians must not be separated from the role of leader that is reflected from the leadership of Soekarno to Joko Widodo today who continue promoting a firm stance rejecting the Israeli occupation in Palestine. This attitude is also a reflection of the domestic situation, especially the people of Indonesia who continue to support the Palestinians and expressed support as well as demands to the government to always take a firm stance related to the Israeli-Palestinian conflicts. In the international context, the involvement of Indonesia in international forums also affected the actions and direction of policies formulated by decision-makers. Indonesia's contribution to maintaining world peace and the attitude is reflected through its support to countries in conflict, especially the Palestinian in various international forums.

\section{Discussion}

\subsection{Indonesia's Positions and Supports for Palestine}

The firm position to fight against any form of colonisation was implemented by Soekarno with refusing to establish diplomatic relations with Israel and started to support Palestinian. ${ }^{[7]}$ This action was continued by Indonesia's next leaders until Joko Widodo. In 1989, under the reign of Soeharto, Indonesia and the representative of the PLO signed an agreement of the diplomatic relations. ${ }^{[8]}$ The struggle of Palestinian to be independent and to have its own right to self-determination was rewarded with achievement to be an observer state in the UN in 2012. And to appreciate it, Indonesia expressed support through the statement of former Foreign Minister Marty Natalegawa. ${ }^{[9]}$ The achievement of Indonesia's stance positon was reflected through the opening of the Honorary Consulate of Indonesia in Ramallah in 2015. ${ }^{[10]}$ Joko Widodo issued a Presidential Decree No. 172/M 2015 on December 21, 2015 regarding to the appointment of Mrs. Maha Abu Shusheh as the Honorary Consul of Indonesia in Ramallah, Palestine. ${ }^{[11]}$

According to humanitarian issues, Indonesian government also provided assistance and foreign aid to the Palestinians. In 2007 Indonesia provided one million US dollars aid to the Palestinians at the Paris Donors Conference. Indonesia also built Indonesian Cardiac Facility at Al Shifa Hospital of Gaza and delivered assistance over one million US dollars to the recovery process after Gaza attack at the time of Cairo International Conference on Palestine. The foreign aids include public facilities such as solar cells, ambulances, etc. ${ }^{[12]}$ In 2008-2013 Indonesia had initiated 128 technical assistance programs and had trained 1,338 Palestinians in the framework of cooperation under NAASP (New Asian-African Strategic Partnership for Palestinian Capacity Building Program), and CEAPAD (Conference on Cooperation Among East Asian Countries for Palestinian Development) which was extended until 2019. In 2016, further cooperation in capacity building program will be earmarked for the Palestinian Police and the Civil Service. ${ }^{[13]}$

While in international arena, the Palestine issues had been a serious concern driven by Indonesia. The issue had taken on the first Asian-African Conference (KAA) which was held in 1955 in Bandung which produced the Dasa Sila Bandung (Ten Principles of Bandung). ${ }^{[14]}$ KAA Summit had inspired the establishment of the NonAligned Movement, and on the first summit of Non-Aligned Movement which held in Beograd, Yugoslavia in $1961,{ }^{[15]}$ the support of the member countries, especially Indonesia to Palestine was actively echoed.

Moreover, when the Non-Aligned Movement summit was held in Jakarta on 10 September 1992, it created the "Jakarta Message", which contained the firm position against Israeli occupation and demand to the withdrawal of Israeli forces from all occupied Arab territories. ${ }^{[16]}$ In the UN forums, when Indonesia became a non-permanent member of the UN Security Council on 2007-2008, Indonesia consistently continued to support the rights of the Palestinians, especially the right to self-determination and also the right to establish an independent state. Indonesia urged the UN Security Council to issue decisions regarding the issue of Palestine, including the Presidential Statement (PRST) and resolution. ${ }^{[17]}$ As the result of Indonesia's insistence, the UN Security Council passed resolution No. 1850 on December 16, 2008 regarding the Middle East peace processes, especially the Israeli-Palestinian. Indonesia also became one of the principle initiators of the Special Session of 
the UN General Assembly in Palestine from 15 to 16 January 2009 and called on the international community to continue to help the humanitarian crisis in Gaza. ${ }^{[18]}$

As a member of the Human Rights Council, Indonesia also pushed for a Special Session of the Human Rights Council on January 9-12, 2009. The outcome was the draft resolution on "the grave violation of human rights in the occupied Palestinian territory, particularly due to the recent Israeli military attacks against the occupied Gaza Strip“" ${ }^{[19]}$ At the Asian-African Conference in 2015, the leaders including Indonesia approved the Declaration on Palestine as an important achievement of the conference. The Declaration contains support from Asian and African countries over the Palestinian struggle for independence and to achieve the two-state solution alongside Israel. The conference also gave birth to a declaration to strengthen the New Asia Africa Strategic Partnership, which also extended support and assistance to the Palestinians by 2019. In 2015, Indonesia also hosted the International Conference on the Question of Jerusalem on 14-16 December 2015 in Jakarta. The conference was in collaboration with the Organization of Islamic Cooperation (OIC) and the United Nations Committee on the Inalienable Rights of the Palestinian People. ${ }^{[20]}$

On March 6-7, 2016 the $5^{\text {th }}$ Extraordinary Summit of Organization of Islamic Cooperation with the theme "United for a Just Solution" was held in Jakarta. The result was the ratification of resolution which reaffirmed the principles and commitment of the OIC to Palestine and Al-Quds Al-Sharif and the Jakarta Declaration as an initiative of Indonesia, which included a concrete plan of OIC leaders to resolve the issue of Palestine and AlQuds Al-Sharif. ${ }^{[21]}$ The concrete support comprised the strengthening of political support to revive the peace process; reconsideration of Quartet (as the Israeli Palestinian peace mediators, comprising the UN, US, EU and Russia) with the possibility of adding members; strengthening pressure on Israel, including a boycott of Israeli products produced in the occupied territories; increasing pressure on the UN Security Council to provide international protection for the Palestinians, and an expiration date of termination of the Israeli occupation. ${ }^{[2]}$

\subsection{The Challenges of Indonesia's Future Relations With Palestine}

The relations between Indonesia and Palestine in the realm of politics and culture have long been good as has been described above. Independent and active foreign policy that are still the main character of Indonesian foreign policy has also been applied quite well in Indonesia and Palestine relations. The opening of the Honorary Consulate in Joko Widodo era as an achievement of Indonesian foreign policy in Palestine should be appreciated, as this becomes the further step of Indonesia's seriousness in supporting peace in Palestine. The Indonesian foreign policy in the era of Joko Widodo more likely a continuation from the foreign policy models of Susilo Bambang Yudhoyono era. During Yudhoyono's era, Indonesia struggled to become a "middle power," and had an active role regionally and globally. In his first ever foreign policy speech, delivered to the Indonesian Council on World Affairs in 2005, he said Indonesia needed to go beyond its traditional "free and active" foreign policy and adopt a "constructive approach" to engage regional and global actors and function as a peacemaker, confidence builder, problem solver, and bridge builder ${ }^{[23]}$ His successor, Joko Widodo, is continuing Yudhoyono's basic foreign policy vision, which has sought to balance raising Indonesia's leadership profile in regional and international, including advancing Jakarta's role as a middle power. ${ }^{[2]}$

Indonesia's supports for the Palestine in international forums such as noted above become a signal to the international community that the position and attitude of Indonesia will always support the Palestinian cause. Indonesia's contributions not only in the terms of bilateral relations with the Palestine but also the role of Indonesia in the international world has long been recognized by the Palestinians. ${ }^{[25]}$ It is a challenge for Indonesia to always maintain the trust of the Palestinian people as well as a challenge that Indonesia must always be active and play a role in campaign the peace. Thus, Indonesia should always struggle to keep having a role in international organizations.

However, despite having been active in supporting the Palestinian struggle, but many supports Indonesia had been providing for decades still not succeeded in pressing the withdrawal of Israeli colonization over Palestine. The fact that Indonesia has not established diplomatic relations with Israel until now would be one of the obstacles of Indonesia's role in promoting peace in the conflict between Israel and Palestine. Another challenge for Indonesia is not only become an initiator for development programs in Palestine but could be a mediator for Israeli-Palestine conflicts. It might be hard due to the absence of diplomatic relations with Israel. Alternatively, Indonesia could become a mediator in the rivalry between Hamas and Fatah in the Palestinian internal politics. It is such a common secret that the main obstacle in the internal political situation of Palestine is a "leadership 
dualism" between Hamas and Fatah in running the Palestinian government. It is also an obstacle for reconciliation progress between Israel and the Palestine. Indonesia's willingness to become a mediator for the Palestinian issues has been struggled in the era of Susilo Bambang Yudhoyono, but it was unclear how to realize the peace since Indonesia is only willing to engage with Palestine while at the same time it is hard for Indonesia to recognize the existence of Israel due to a strong resistance which come from particularly the Muslim community groups in Indonesia. ${ }^{[26]}$

President Joko Widodo held a bilateral meeting with Palestinian President Mahmoud Abbas between the series events of the 5th Extraordinary Summit of Organization of Islamic Cooperation which held in Jakarta on 6-7 March 2016. During the meeting Joko Widodo delivered a support to the Palestinian struggle for independence in accordance with the framework of a two-state solution. ${ }^{[27]}$ But it became quite difficult for Indonesia to support the framework of a two-state solution for Palestine and Israel while Indonesia tends to only support to one side. The absence of diplomatic relations with Israel becomes a paradox of the Indonesia's seriousness to support the two-state solution for Palestine and Israel issues. Meanwhile, the effort to establish a serious relation between Indonesia and Israel had been around a long time since the end of Soeharto era in the 1990s. ${ }^{[28]}$ The effort was intensified in President Abdurrahman Wahid era who urged to cooperate with Israel, especially in the trade sector. ${ }^{[29]}$ For Wahid, the idea was in line with Indonesia's interests for recoveries after the economy crisis. Israel trade relations with Indonesia would also strengthen Indonesian lobbying in international stage and would be potential for Indonesia's export activity. ${ }^{[30]}$ The harsh reactions came from conservative Indonesian Islamist groups who opposed the idea of establishing diplomatic relation with Israel. ${ }^{[31]}$ The official relation between Israel and Indonesia is not yet established, but we do not deny that Indonesia has established unofficial relations with Israel in terms of economic and military cooperation.

It is understandable that Indonesian domestic conditions become the driving factor in formulating the government's foreign policy. In relation to the issues of Palestine, the people of Indonesia are actively involved in supporting the Palestinian cause not only through the support or advice to the government but also move independently as non-state actors. There are two factors underlying this case: first, humanitarian solidarity and second, religious solidarity. The first factor is certainly more dominating than the second factor yet it can't be denied that the majority of Indonesian people are Muslims. Both factors support each other so that solidarity is based on the humanitarian empathy motivated by religious obligation to uphold the truth and against the falsehood. For Indonesian government, to show the further serious involvement in foreign policy on the Palestine and Israel issues, it is necessary for Indonesia to reconsider a clear position concerning the existence of Israel in the eyes of Indonesia, whether by reconsidering to establish official relations with Israel can facilitate Indonesia's interests related to Palestinian-Israeli issues or will continue to limitedly launch the political and assistance supports to the Palestinians alone. These two things will certainly be a big challenge for Indonesia in the future, particularly the efforts to establish formal relations with Israel. The greatest thing in this challenge is various reactions of the Indonesian people, especially the Muslim communities.

\section{Acknowledgements}

This paper in a collaboration with Dr. Muhammad Luthfi Zuhdi, a Senior lecturer at Faculty of Humanities Universitas Indonesia and also as the Head of Postgraduate School program of Middle Eastern and Islamic Study Center at Universitas Indonesia.

\section{References}

[1] M. Sabir, Politik Bebas Aktif, Jakarta: Haji Masagung, 1987, p.13

[2] M. Hatta, "Indonesian Foreign Policy", Foreign Affairs, Vol. 31 No. 3, April, 1853, p. 444

[3] M. Hatta, Mendayung Antara Dua Karang, Jakarta: Bulan Bintang, 1976, p. 17

[4] Abubakar Eby Hara, Pengantar Analisis Politik Luar Negeri dari Realisme sampai Konstruktivisme, Bandung: Nuansa, 2011, p. 89

[5] Ibid, p. 90

[6] Ibid.

[7] Denny Lesmana, Dukungan Indonesia untuk Palestina, Direktorat Timur Tengah Kementerian Luar Negeri RI, Jakarta: CV. Hilda, 2014, p. ix 
[8] Ibid, p. 10

[9] United Nations Official Website, "General Assembly Votes Overwhelmingly to Accord Palestine "Non-Member Observer State' Status in United Nations”, November 29 2012, https://www.un.org/press/en/2012/ga11317.doc.htm retrieved December 182016

[10] Ministry of Foreign Affairs of Republic of Indonesia, "Pembukaan Konsul Kehormatan RI di Ramallah", March 10 2016, http://www.kemlu.go.id/id/berita/siaran-pers/Pages/Pembukaan-Konsul-Kehormatan-RI-di-Ramallah.aspx retrieved December 182016

[11] KBRI Amman, "Menlu RI Lantik Konsul Kehormatan RI Untuk Palestina", March 132016 http://www.kemlu.go.id/amman/id/berita-agenda/berita-perwakilan/Pages/MENLU-RI-MELANTIK-KONSULKEHORMATAN-RI-UNTUK-PALESTINA-DI-AMMAN---YORDANIA.aspx retrieved December 182016

[12] Ministry of Foreign Affairs of Republic of Indonesia: http://www.kemlu.go.id/en/berita/Pages/indonesia-commitmentpalestine-israel-peace.aspx retrieved December 182016

[13] Ministry of Foreign Affairs of Republic of Indonesia, "The Palestinian Issue", January 20 2016, http://www.kemlu.go.id/en/kebijakan/isu-khusus/Pages/The-Palestinian-Issue.aspx retrieved December 192016

[14] A.W. Widjaja, Indonesia, Asia-Afrika, Non Blok, Politik Bebas Aktif, Jakarta: Bina Aksara, 1986, p. 26

[15] Ibid, p. 31

[16] Riza Sihbudi, Indonesia-Timur Tengah: Masalah dan Prospek, Jakarta: Gema Insani Press, 1987, p. 51

[17] Ministry of Foreign Affairs of Republic of Indonesia, "The Palestinian Issue", January 20 2016, http://www.kemlu.go.id/en/kebijakan/isu-khusus/Pages/The-Palestinian-Issue.aspx retrieved December 192016

[18] Ibid.

[19] Ibid.

[20] Ibid.

[21] Official Website of Presiden Republik Indonesia, "Mengakselerasi Kemerdekaan Palestina", March 8 2016, http://presidenri.go.id/internasional/mengakselerasi-kemerdekaan-palestina.html retrieved December 202016

[22] Ibid.

[23] Prashanth Parameswaran, "Between Aspiration and Reality: Indonesian Foreign Policy After the 2014 Elections", The Washington Quarterly, Vol. 37 No. 3 pp. 153-165, The Elliott School of International Affairs, 2014, p. 154

[24] Ibid, p. 157

[25] Interview with Fariz Mehdawi, Palestinian Ambassador for Indonesia, on April 62015

[26] Ganewati Wuryandari, "Politik Luar Negeri Indonesia: Refleksi dan Prediksi 10 Tahun", Jurnal Penelitian Politik, Vol 5, No 1 (2008): Problematika Reformasi, p. 65

[27] Official Website of The 5th Extraordinary OIC Summit on Palestine and Al-Quds Al-Sharif, "Pertemuan Bilateral Palestina-Indonesia KTT Luar Biasa OKI Ke-5", https://oic-es2016.id/?lang=id\&p=detrelease\&id=24, retrieved December 232016

[28] Greg Barton and Colin Rubenstein, "Indonesia and Israel: A Relationship in Waiting”, Jewish Political Studies Review, Vol. 17, No. 1/2, Spring 2005, p. 165

[29] Suhartono, Analisis Kebijakan Luar Negeri Pemerintahan Abdurrahman Wahid (1999-2000), Tim Peneliti Hubungan Internasional Pusat Pengkajian dan Pelayanan Informasi Dewan Perwakilan Rakyat Republik Indonesia, 2001, p. 183

[30] Ibid., p. 184

[31] Greg Barton and Colin Rubenstein, ” Indonesia and Israel: A Relationship in Waiting”, p. 165 